02

\title{
Спектрофотометрическое исследование солей нитратов и нитритов и их водных растворов
}

\author{
() Н.Л. Алукер ${ }^{1}$, M.E. Herrmann², Я.М. Суздальцева ${ }^{3}$ \\ ${ }^{1}$ Кемеровский государственный университет (КемГУ), \\ 650000 Кемерово, Россия \\ ${ }^{2}$ Department of Meteorology, Pennsylvania State University, \\ PF, USA \\ ${ }^{3}$ Институт экологии человека, \\ 650065 Кемерово, Россия \\ e-mail: naluker@gmail.com
}

Поступила в редакцию 03.03.2019 г.

В окончательной редакции 15.05.2019 г.

Принята к публикации 20.06.2019 г.

\begin{abstract}
Исследованы оптические характеристики солей нитратов и нитритов и их водные растворы с целью демонстрации применения прямых спектрофотометрических методов для определения различных форм солей азота в воде. Приведены примеры применения метода для определения нитрат-иона в пробах природных и питьевых вод из скважин.
\end{abstract}

Ключевые слова: нитрат-ион, нитрит-ион, люминесценция, оптическое поглощение.

DOI: $10.21883 /$ OS.2019.12.48684.95-19

\section{Введение}

Развитие методов определения разных форм растворенных в воде соединений азота актуально, так как позволяет проводить оценку экологической безопасности воды. Фиксация атмосферного азота в природе происходит по двум основным направлениям. Первый путь включает реакции азота с кислородом. Азот химически инертен и для его окисления требуются большие количества энергии. Эти условия достигаются при высоких температурах, при разрядах молний или действием на смесь азота с кислородом ионизирующих излучений. При этом происходит образование различных оксидов азота. В результате деятельности бактерий (второй путь) молекулярный азот может преобразовываться в соединения аммония $\left(\mathrm{NH}_{4}^{+}\right)$. Азот в форме аммиака и соединений аммония быстро окисляется до нитратов и нитритов (этот процесс носит название нитрификации). В процессе денитрификации нитраты восстанавливаются до нитритов, аммиака и молекулярного азота [1-3]. Большинство нитратов и нитритов хорошо растворимы в воде, поэтому они вымываются водой и попадают в мировой океан.

Содержание нитратов в природных водах обычно небольшое, однако под влиянием антропогенных факторов их концентрация может увеличиваться до сотен и даже тысяч mg/l. Предельно допустимая концентрация (ПДК) иона $\mathrm{NO}_{3}^{-}$для питьевой воды составляет $45 \mathrm{mg} / \mathrm{l}$. Соли азотной кислоты (нитраты) являются конечным продуктом минерализации органических азотсодержащих веществ, поэтому в случае отсутствия аммиака и со- лей азотистой кислоты наличие нитратов будет являться показателем законченной минерализации органических веществ.

Наличие в воде нитратов и одновременное присутствии нитритов и аммиака указывает на то, что процессы минерализации органических веществ еще не закончены, и поступление органических загрязнений продолжается. Соли азотистой кислоты $\left(\mathrm{HNO}_{2}\right)$ являются неустойчивым компонентом природных вод, поскольку в окислительной обстановке переходят в нитраты [4,5]. Нитриты - высокотоксичные соединения, более опасные для здоровья человека, чем нитраты. Предельно допустимая концентрация иона $\mathrm{NO}_{2}^{-}$для питьевой воды составляет $3.3 \mathrm{mg} / \mathrm{l}$. Повышенное содержание $\mathrm{NO}_{2}^{-}$в грунтовых водах обычно указывает на „свежее“ загрязнение и является важным санитарным показателем. В связи с этим возникает необходимость изучения и оценки содержания нитратов и нитритов прямыми методами для внедрения их в практику контролирующих состояние водных ресурсов организаций.

В настоящей работе была поставлена задача исследования спектров поглощения водных проб, содержащих соли нитратов и нитритов металлов, с целью определения их оптических характеристик в растворах. Проведены также исследования твердой кристаллической матрицы солей нитратов и нитритов. Это позволило предложить простую и экспрессную методику раздельного определения растворенных в воде нитратов и нитритов без применения пробоподготовки и химических реактивов для создания окрашенных форм. 


\section{Методы определения различных форм азота в воде}

Для определения различных форм азота в воде используют так называемые методы „мокрой химии“ [2-5].

Для определения содержания аммонийного азота, как правило, применяют относительно недорогой и простой фотометрический метод с использованием реактива Несслера. На результат анализа оказывает влияние состав пробы, в частности, присутствие органических соединений, что увеличивает погрешность измерения.

Для контроля содержания нитратов также используется фотометрический метод (основанный на реакции нитратов с салицилатом натрия). Определению мешает присутствие в анализируемой пробе окрашенных веществ, а также нитрит-иона.

Определение массовых концентраций нитрит-иона может быть выполнено по реакции нитрита с реактивом Грисса в фильтрате с удаленным белком с последующим измерением интенсивности окраски на фотоколориметре. Используется также метод окисления нитритов до нитратов персульфатом аммония. Разность между найденным суммарным содержанием нитрат-ионов и начальной концентрацией нитрат-ионов равна концентрации нитрит-ионов.

Нередко используется показатель „содержание азота по Кьельдалю“ (сумма органического и аммонийного азота). Для определения этого показателя требуется длительное кипячение пробы в концентрированной серной кислоте, отгонка аммиака, а затем титрометрическое и фотометрическое измерения. Весь процесс достаточно длительный, трудоемкий и связан с использованием опасных веществ. Этот показатель не дает полной характеристики исследуемой пробы по содержанию азота, поскольку азот нитратов и азот нитритов исключаются из рассмотрения.

При анализе сточных вод используют показатель „общий азот“, определяемый как сумма содержания всех растворимых форм органического и неорганического азота. Однако не существует единого аналитического метода для определения общего органического азота. Этот показатель рассчитывается математически как разность между содержанием общего азота и неорганического азота.

Все описанные методы непрямые, трудоемкие, зависят от состава пробы и не дают однозначного результата. В настоящее время происходит переориентация методов химической аналитики на использование автоматизированных приборов, позволяющих получать достоверную информацию об объекте исследования быстрее, с меньшими трудозатратами и возможностью исключения субъективных ошибок. Наиболее перспективное направление связано с использованием оптических методов исследования (прямого оптического поглощения с хорошим разрешением и люминесценции). Наибольшее количество исследований определения соединений

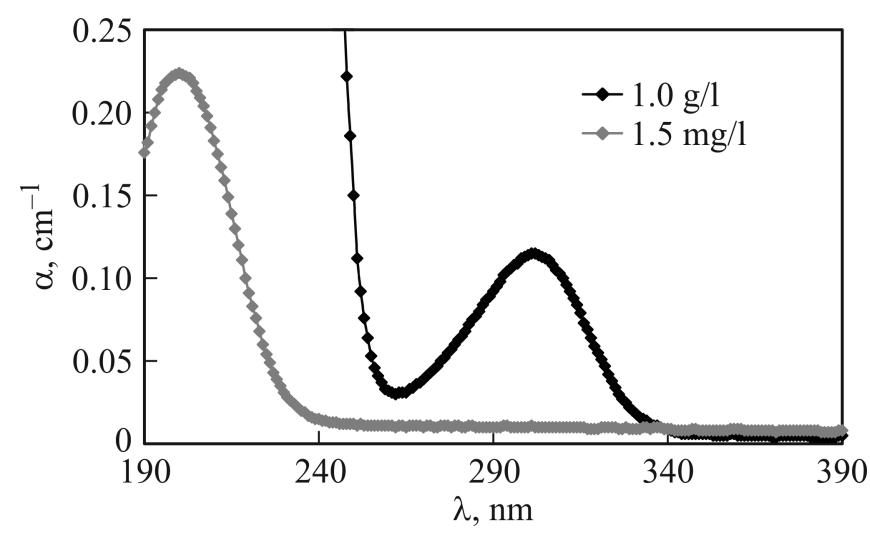

Pис. 1. Спектры оптического поглощения раствора нитрата калия в бидистиллированной воде.

азота в газах связано с использованием лазерного излучения [6-14]. Оксид азота NO определяют по поглощению излучения в УФ и ИК областях спектра $(214$ и $226 \mathrm{~nm}$ и $5.3 \mu \mathrm{m})$. Диоксид азота $\mathrm{NO}_{2}$ определяют по поглощению излучения в УФ и ИК областях спектра $(249,420-485 \mathrm{~nm}$ и $6.34 \mu \mathrm{m})$. Полоса поглощения молекулы $\mathrm{NO}_{2}$ в области $424-448 \mathrm{~nm}$ структурирована. Поглощение аммиака в УФ области (при $204.3 \mathrm{~nm}$ и атмосферном давлении) было использовано для прямого определения его низких концентраций в воздухе.

Практически все азотсодержащие соединения достаточно хорошо поглощают свет, но результаты спектрофотометрических исследований довольно неоднозначны, проявляется зависимость от условий наблюдения, чистоты соединений, используемых растворителей [6-14]. В связи с этим нами проведены исследования спектров поглощения нитратов и нитритов металлов в воде при единых условиях для определения их оптических характеристик в водных растворах, а также в твердой кристаллической матрице. Измерения проводились на спектрофотометре „SHIMADZU UV-1700“ в диапазоне $190-1100 \mathrm{~nm}$. В качестве растворителя использовалась бидистиллированная вода.

\section{Результаты исследования}

Нитрат- и нитрит-ионы в водном растворе сильно поглощают свет в УФ области. Нитрат-ион имеет полосы оптического поглощения с максимумами в областях 200 и $300 \mathrm{~nm}$. В водных растворах соли азотной кислоты могут быть определены по этим пикам. Нитрит-ион интенсивно поглощает свет в полосах с максимумами при 210 и $355 \mathrm{~nm}$.

На рис. 1 приведены спектры оптического поглощения водного раствора нитрата калия при разных концентрациях соли в растворе. По оси ординат приведен десятичный показатель поглощения. При концентрации нитрата натрия $1.5 \cdot 10^{-3} \mathrm{~g} / 1$ наблюдается полоса поглощения с максимумом при $202 \mathrm{~nm}$. При концентрации 


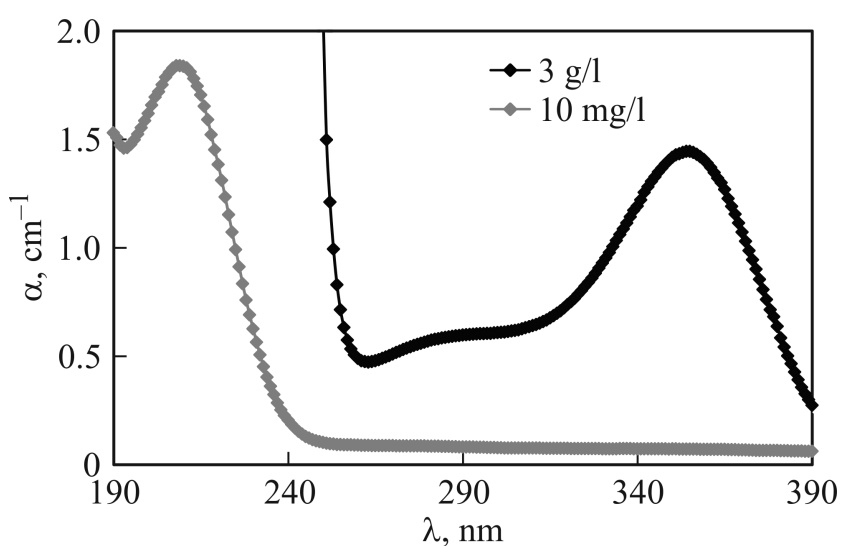

Pис. 2. Спектры оптического поглощения раствора нитрита натрия в бидистиллированной воде.

$1 \mathrm{~g} / 1$ поглощение с максимумом $202 \mathrm{~nm}$ не наблюдается, а десятичный показатель поглощения $\alpha$ в полосе $302 \mathrm{~nm}$ составляет $\sim 0.115 \mathrm{~cm}^{-1}$. Молярные коэффициенты экстинкции полос таким образом отличаются более, чем в $\sim 1000$ раз. Для длинноволновой полосы $\varepsilon \sim 71 / \mathrm{mol} \cdot \mathrm{cm}$. По полосе поглощения $202 \mathrm{~nm} \mathrm{в}$ отсутствие других примесей, поглощающих в данной области, может быть измерено содержание нитрат-иона в воде при концентрациях в диапазоне 0.1-200 mg/l, а по полосе поглощения $302 \mathrm{~nm}$ - при концентрации выше $40 \mathrm{mg} / \mathrm{l}$.

На рис. 2 приведены спектры поглощения нитрита натрия при разных концентрациях соли в растворе. Молярный коэффициент экстинкции полосы $355 \mathrm{~nm}$ составляет $\sim 231 / \mathrm{mol} \cdot \mathrm{cm}$ и превышает $\varepsilon$ полосы поглощения $300 \mathrm{~nm}$ в нитрате натрия в $\sim 4$ раза. Молярные коэффициенты экстинкции полос $202 \mathrm{~nm} \mathrm{NO}-$ и $210 \mathrm{~nm} \mathrm{NO}_{2}^{-}$ отличаются в меньшей степени. В области 260-310 nm в нитратах наблюдается поглощение, которое, исходя из литературных данных, может быть связано с поглощением $\mathrm{NO}_{2}(275 \mathrm{~nm}) \varepsilon \sim 201 / \mathrm{mol} \cdot \mathrm{cm} \mathrm{и}(290 \mathrm{~nm})$ $\varepsilon \sim 91 / \mathrm{mol} \cdot \mathrm{cm}[7,8]$. Содержание нитрит-иона в полосе $210 \mathrm{~nm}$ может быть измерено, начиная с концентраций $0.1 \mathrm{mg} / \mathrm{l}$ до $200 \mathrm{mg} / \mathrm{l}$, а в полосе $355 \mathrm{~nm}$ - от $20 \mathrm{mg} / \mathrm{l}$.

На рис. 3 приведены спектры поглощения $1 \mathrm{M}$ растворов для ряда нитратных солей в энергетических координатах, из которых определяются коэффициенты молярной экстинкции для полос поглощения. Данные получены на основании измерения концентрационных зависимостей, из которых определены коэффициенты молярной экстинкции для полос поглощения. Видно, что коэффициенты молярной экстинкции $71 / \mathrm{mol} \cdot \mathrm{cm}$ и $\sim 90001 / \mathrm{mol} \cdot \mathrm{cm}$ и оптические характеристики (положение максимумов и полуширины полос) иона $\mathrm{NO}_{3}^{-}$ очень стабильны и практически не зависят от катиона. Полуширина полосы $4.1 \mathrm{eV}(302 \mathrm{~nm})$ составляет $0.42 \mathrm{eV}$, а полуширина полосы $6.14 \mathrm{eV}(202 \mathrm{~nm})$ равна $0.94 \mathrm{eV}$. В связи с этим использование молярных коэффициентов экстинкции позволяет однозначно определять кон- центрации нитрат-ионов в воде в широком диапазоне концентраций вне зависимости от катиона.

Аналогичная картина наблюдается и для растворов нитритов в воде. Коэффициенты молярной экстинкции $23 \mathrm{l} / \mathrm{mol} \cdot \mathrm{cm}$ и $\sim 6500 \mathrm{l} / \mathrm{mol} \cdot \mathrm{cm}$, положение максимумов $5.9 \mathrm{eV}(210 \mathrm{~nm}), 3.5 \mathrm{eV}(355 \mathrm{~nm})$, полуширины полос соответственно 0.42 и $0.8 \mathrm{eV}$. Оптические характеристики полос также не зависят от катиона. Кроме этих полос в спектре поглощения появляется широкая неэлементарная полоса в области $3.8-4.8 \mathrm{eV}$. Эта полоса хорошо аппроксимируется суммой полос поглощения 4.1 и $4.54 \mathrm{eV}$. Вероятно, в поглощении нитритов в воде присутствуют полосы поглощения $4.1 \mathrm{eV}$ с полушириной $0.42 \mathrm{eV}$ и $4.54 \mathrm{eV}$ с полушириной $0.44 \mathrm{eV}$ (рис. 4).

\section{Поглощение и люминесценция кристаллических нитратов}

Следует отметить, что в кристаллических нитратах наблюдается поглощение, аналогичное водным растворам [15-17]. В связи с тем, что для измерения собственного поглощения кристаллов в УФ области необходимо работать с тонкими пленками, измерялись кристаллы
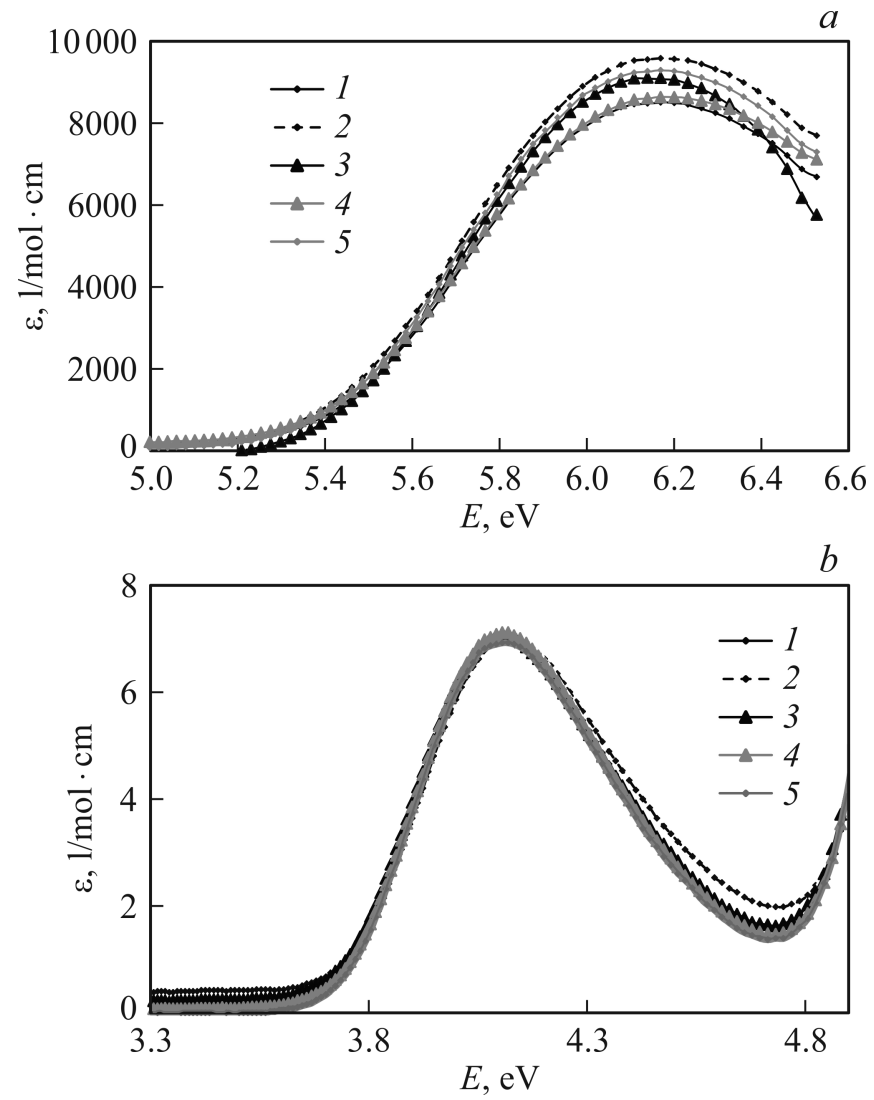

Pис. 3. Спектры оптического поглощения: $1-\mathrm{KNO}_{3}, 2-$ $\mathrm{Co}\left(\mathrm{NO}_{3}\right)_{2}, 3-\mathrm{CsNO}_{3}, 4-\mathrm{NaNO}_{3}, 5-\mathrm{NH}_{4} \mathrm{NO}_{3}$ в бидистиллированной воде. (a) Высокоэнергетическая полоса $(6.14 \mathrm{eV}), \varepsilon \sim 90001 / \mathrm{mol} \cdot \mathrm{cm},(b)$ низкоэнергетическая полоса $(4.1 \mathrm{eV}), \varepsilon \sim 71 / \mathrm{mol} \cdot \mathrm{cm}$. 


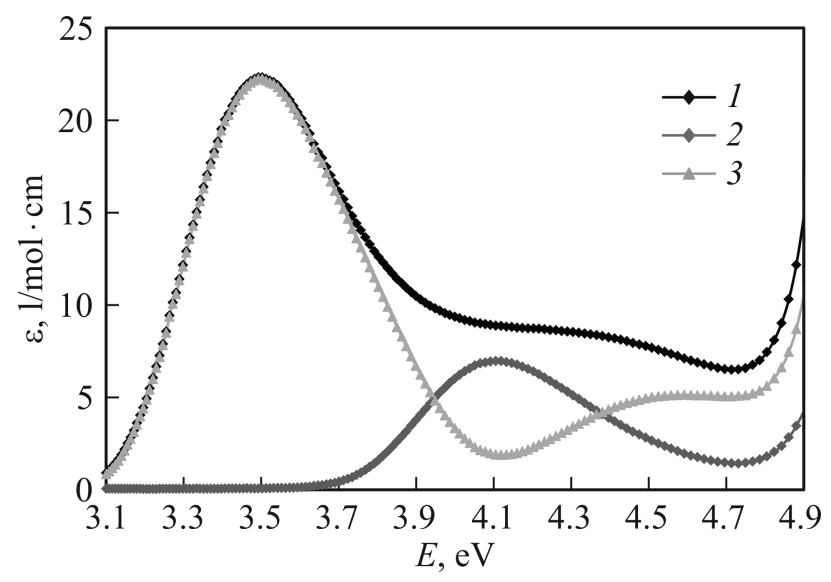

Рис. 4. Разложение низкоэнергетической части спектра оптического поглощения $\mathrm{NaNO}_{2}$ в бидистиллированной воде: 1 спектр поглощения нитрит-иона в воде, экспериментальный; 2 - спектр поглощения нитрит-иона в воде, экстраполированный; 3 - разностный спектр поглощения.

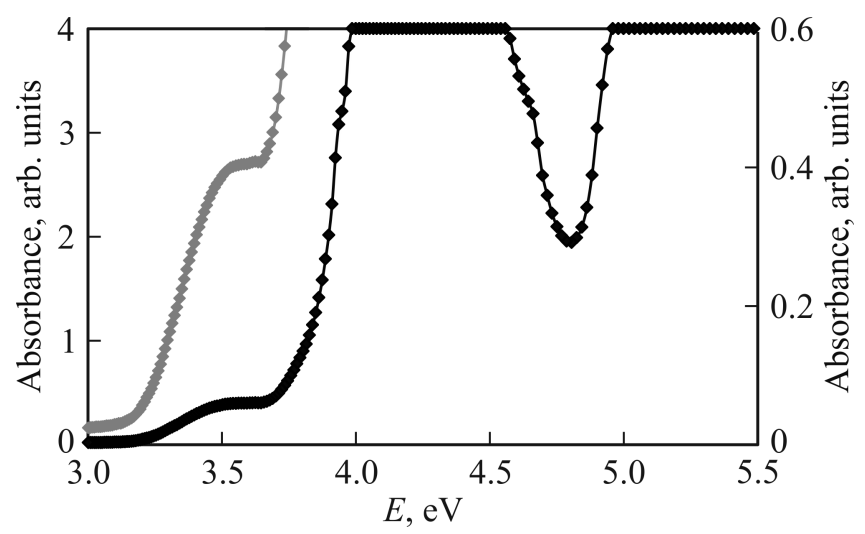

Рис. 5. Спектр поглощения кристалла $\mathrm{NaNO}_{3}$, легированного $0.35 \% \mathrm{NO}_{2}$.

$\mathrm{NaNO}_{3}$, легированные $\mathrm{NO}_{2}$. Спектр поглощения кристалла $\mathrm{NaNO}_{3}$, легированного $0.35 \% \mathrm{NO}_{2}$, приведен на рис. 5. Надежно фиксируется примесное поглощение нитрит-иона, а для основы $\left(\mathrm{NaNO}_{3}\right)$ измерить поглощение не удается. Однако ясно, что полоса расположена в области 4-4.5eV, т.е. в области, где расположена полоса поглощения нитрат-иона в водной среде $(4.1 \mathrm{eV})$.

В спектрах поглощения кристаллических нитратов при измерении очень тонких слоев кристалла удается зарегистрировать полосу поглощения $4.1 \mathrm{eV}$. Ультрафиолетовая область исследована в спектрах отражения. В работах В.А. Невоструева с соавторами для ряда нитратных соединений приводятся характеристики поглощения нитрат-ионов [8]. Характеристики поглощения нитрат-иона в кристаллах совпадают с растворами как по соотношению сил осцилляторов, так и по полуширинам полос.

В более сложных органических молекулярных кристаллах, содержащих связи $\mathrm{O}-\mathrm{NO}_{2}$, например, пентаэ- ритриттетранитрат (PETN), край поглощения кристалла совпадает с длинноволновой частью полосы поглощения нитрат-иона, а в растворах проявляются полосы поглощения $\sim 202$ и $270 \mathrm{~nm}$, характерные для нитрат-иона и нитрогруппы [9].

В водном растворе и в $\mathrm{N}, \mathrm{N}$-диметилформамиде (ДМФА) в поглощении РЕТN наблюдаются полосы в области $350 \mathrm{~nm}$, причем в ДМФА наблюдается колебательная структура полосы, связываемая с поглощением HONO [10], появляющаяся в растворах нитритов при их окислении (рис. 6).

Расчеты зонной структуры нитратов показывают, что верхняя заполненная валентная зона образуется в основном из $2 p$-состояний кислорода ( $n$ электронов, не принимающих участие в образовании химической связи), а самая нижняя незанятая зона определяется атомами кислорода и азота, ее можно рассматривать как подзону в запрещенной зоне, где верхняя зона проводимости определяется катионами [18-20]. Нижняя незанятая зона построена преимущественно из состояний анионной природы. Ее кристаллические орбитали в большей мере состоят из $\pi$-орбиталей атома азота и $\pi$-орбиталей атома кислорода $[18,19]$.

Стабильность поглощения нитрат- и нитрит-ионов в водных растворах и кристаллах в широком диапазоне концентрации и независимость сечения поглощения от свойств катионов свидетельствуют об изолированности ионов и развитии процессов в анионной подрешетке, скорее всего, внутрицентровом характере поглощения в нитрит- и нитрат-ионах (азот-кислород).

Нитрат- и нитрит-ионы являются энергетически нестабильными и диссоциируют при энергии меньше $2.13 \mathrm{eV}$ $(582 \mathrm{~nm})\left[\mathrm{NO}_{2}-\mathrm{O}\right], 4.5 \mathrm{eV}(276 \mathrm{~nm})\left[\mathrm{N}-\mathrm{O}_{2}\right]$ и $3.11 \mathrm{eV}$ $(399 \mathrm{~nm})[\mathrm{NO}-\mathrm{O}]$. Следовательно, при возбуждении этих молекулярных ионов в области поглощения с энергиями больше $2.13 \mathrm{eV}$ для нитрат-иона и $3.11 \mathrm{eV}$ для нитрит-иона осуществляется их диссоциация. При этом часть энергии возбуждения тратиться на диссоциацию, а оставшаяся на возбуждение продуктов диссоциации. Аннигиляция диссоциированных продуктов может при-

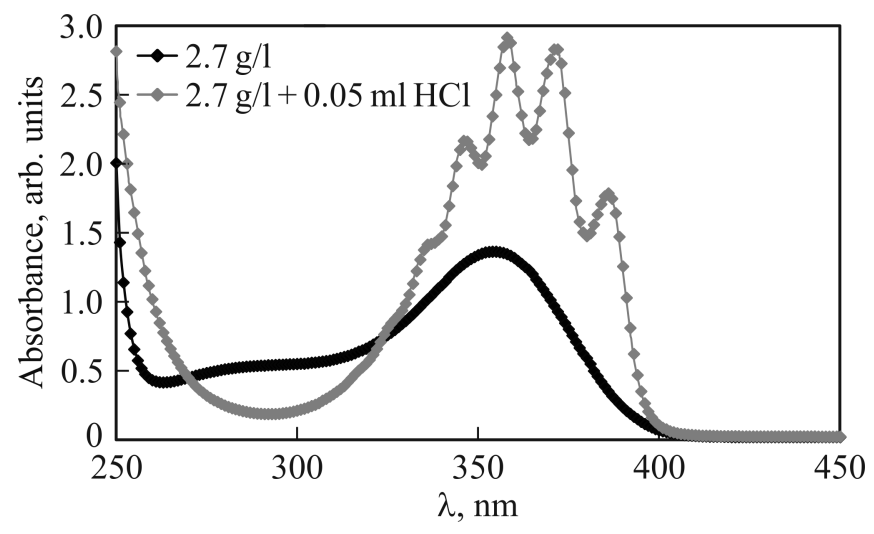

Рис. 6. Спектр поглощения водного раствора $\mathrm{NaNO}_{2}$ с каплей $\mathrm{HCl}$. 
водить к излучению (т.е. к люминесценции экситонов). Передача возбуждения одному из возбужденных продуктов приводит к внутрицентровой люминесценции продукта диссоциации. Таким образом, можно было бы рассчитывать на наблюдение как экситонной люминесценции, так и люминесценции возбужденных продуктов диссоциации, однако ни нитраты, ни нитриты не обладают выраженной люминесценцией, что свидетельствует о слабом разделении пар и больших временах жизни продуктов диссоциации, в течение которых велика вероятность безызлучательной рекомбинации.

Тем не менее, для нитратов и нитритов в кристаллическом состоянии и водных растворах при микросекундном возбуждении наблюдается слабая люминесценция в области 320-560 nm [21-24]. Люминесценция может быть связана только с продуктами диссоциации $\mathrm{N}, \mathrm{NO}$, $\mathrm{O}_{2}$, О. В широкой области возбуждений наблюдаются преимущественно полосы люминесценции в области 370 и $440 \mathrm{~nm}$. В возбуждении этой люминесценции всегда присутствует полоса $\sim 275 \mathrm{~nm}$, совпадающая по энергии с энергией диссоциации нитрит-ионов на $\mathrm{N}$ и $\mathrm{O}_{2}$.

\section{Спектры поглощения природных вод и вод, прошедших водоподготовку}

Состояние водных объектов, особенно являющихся источниками питьевой воды для населения, одна из главных текущих экологических проблем. Потребности населения в питьевой воде в местах его проживания осуществляются через централизованные или нецентрализованные системы питьевого водоснабжения. Источниками централизованного водоснабжения являются поверхностные воды, доля которых в общем объеме водозабора составляет $68 \%$, и подземные воды - $32 \%$. В сельской местности преобладает использование в питьевых целях сооружений и устройств систем децентрализованного хозяйственно-питьевого водоснабжения.

В различных аналитических лабораториях страны специалисты ежегодно выполняют не менее $10^{8}$ анализов качества воды. Стоимость комплексного анализа качества питьевой воды очень высока, так как анализы трудоемки и обычно требуют применения дорогостоящих химических соединений, поэтому простые методики оценки загрязнения вод несомненно представляют интерес. Наиболее перспективное направление связано с использованием оптических методов исследования (прямого оптического поглошения с хорошим разрешением и люминесценции).

В спектрах поглощения поверхностных природных вод (рис. 7) в УФ области наблюдается поглощение в области $202 \mathrm{~nm}$, характерное для поглощения нитратиона. Концентрации нитрат-ионов в поверхностных водах существенно ниже ПДК. Длинноволновый хвост поглощения обусловлен, вероятнее всего, рассеянием на взвешенных частицах, присутствующих в водах, не прошедших водоподготовку.

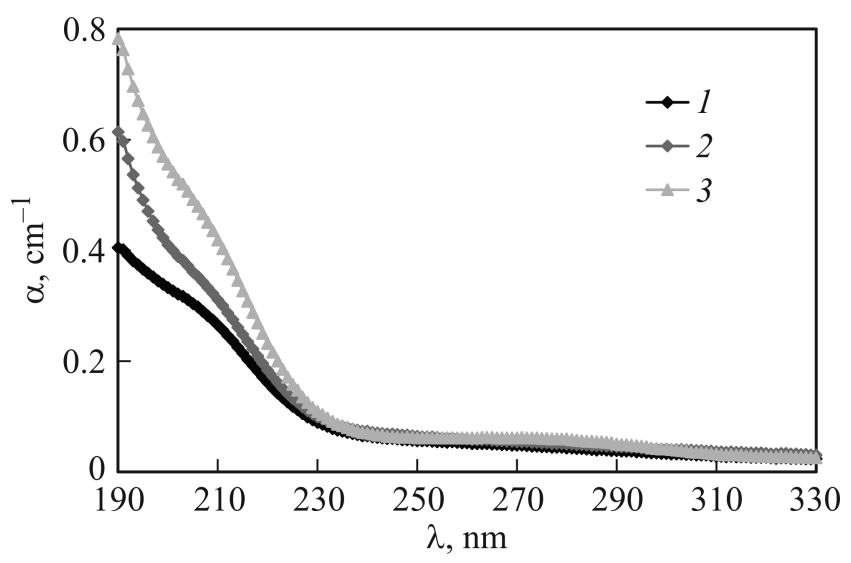

Рис. 7. Спектры оптического поглощения речных вод Кемеровской области: 1 - р. Назас, 2 - p. Уса, 3 - р. Томь.

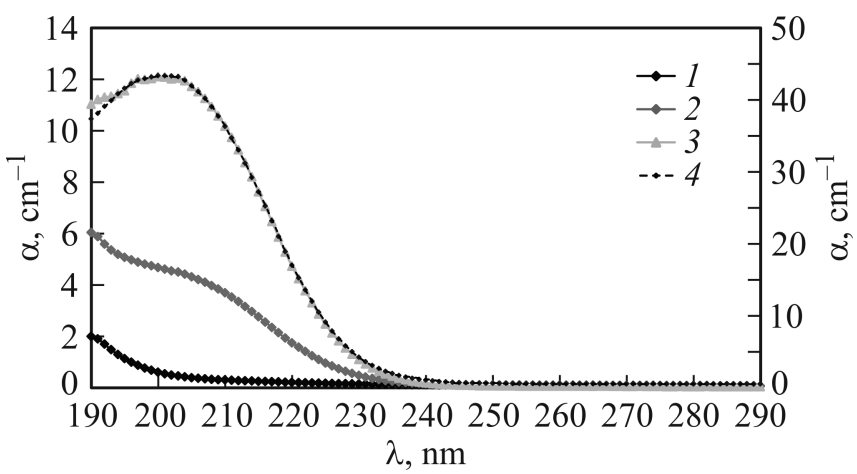

Рис. 8. Спектры оптического поглощения питьевых вод в разных населенных пунктах Кемеровской области: 1 - пгт. Промышленная; 2 - п. Урск; 3 - п. Ариничево (святой источник); 4 - п. Ариничево (правая ось ординат).

Качество централизованных водопроводных вод в основном определяется характеристиками поверхностных источников, откуда организован водозабор и характеризуется большей, чем у рек, прозрачностью в длинноволновой области, обусловленной водоподготовкой (очисткой от взвешенных частиц) и несколько более сильным поглощением в УФ области, возможно, обусловленной процессом водоподготовки и состоянием трубопроводов.

На водозаборы и подготовку вод для питьевых нужд населения в крупных городах Кемеровской области обычно поступают воды из поверхностных источников, и ситуация с водами, прошедшими водоподготовку, контролируется и укладывается в нормативы. Однако в небольших селах и поселках, где в основном для питьевых нужд используются неглубокие скважины, ситуация более сложная. Спектры поглощения питьевых вод из подземных источников (скважины, колодцы, родники) часто обладают сильным поглощением в области 190-220 nm, что отличает их от поверхностных вод.

На рис. 8 представлены спектры поглощения питьевых вод, поступающих населению в качестве водопроводной воды. Наличие в поглощении длинноволнового мак- 
симума при $302 \mathrm{~nm}$, положение и полуширины полос однозначно диагностируют в данных водах нитрат-ионы. Причем содержание их в питьевой воде, отобранной из крана в П.Ариничево, соответствует концентрации $\sim 270 \mathrm{mg} / \mathrm{l}$, а в святой воде $80 \mathrm{mg} / \mathrm{l}$, что превышает ПДК в 6 и почти в 2 раза соответственно. Кипячение воды не влияет на содержание нитрат-ионов в воде. Фильтрация воды бытовыми фильтрами при таких больших концентрациях нитратов приводит к их насыщению после очистки менее одного литра воды. В пробах колодезной воды ряда населенных пунктов Кузбасса (г. Кисилевск, п.Итат, п. Урск, п. Ариничево, п. Бархатово, г. Междуреченск), шахтной воды и воды из отстойников наблюдается повышенные по сравнению с ПДК содержания нитрит- и нитрат-ионов.

Это требует разработки специальной программы по изучению содержания нитратов в питьевых водах в тех поселениях, где основной водозабор ведется из подземных источников, изучению родниковой подземной воды (святые источники) и анализу статистики с сопоставлением ее с заболеваемостью населения, особенно младенческого возраста. Комплексный или расширенный анализ воды является чрезвычайно дорогостоящим, поэтому даже при поставленном контроле перечень контролируемых параметров невелик и все равно трудоемок и довольно дорог.

В настоящей работе для первичного анализа воды применен метод регистрации спектров поглощения непосредственно отобранных вод - без концентрирования, подкисления, внесения катализаторов, рекомендованных для анализа некоторых компонентов. В спектре проявляются только растворенные в воде примеси, биологические компоненты и коллоидные частицы минимальных размеров (более крупные выпадают с течением времени в осадок). Исследование показывает, что метод позволяет быстро определять находящиеся в воде растворенные азотсодержащие соединения.

Таким образом, изучение и анализ спектров поглощения воды без применения предварительной пробоподготовки позволяет надежно определять растворенные в ней нитрат- и нитрит-ионы и проводить аналитическую оценку их содержаний в воде.

\section{Конфликт интересов}

Авторы заявляют, что у них нет конфликта интересов.

\section{Список литературы}

[1] Feuer H. (ed.) The chemistry of the nitro and nitroso groups. John Wiley \& Sons, 1969. 536 р.; Химия нитрои нитрозогрупп / Под ред. Фойера Г. М.: Мир, 1972. Т. 1. $536 \mathrm{c}$.

[2] Майстренко В.Н., Клюев Н.А. Эколого-аналитический мониторинг стойких органических загрязнителей [Электронный ресурс] Режим доступа:

http://www.studentlibrary.ru/book/ISBN9785996326082.html
[3] Фомин Г.С. Вода. Контроль химической, бактериальной и радиационной безопасности по международным стандартам / Энциклопедический справочник, 4-е изд. М.: Протектор, 2010. 1008 с.

[4] Ягов Г.В. // Вода: химия и экология. 2009. № 10. С. 28.

[5] Москвин А.Л., Москвин Л.Н. // Успехи химии. 2005. Т. 74. № 2. C. 155; Moskvin A.L., Moskvin L.N. // Russ. Chem. Rev. 2005. V. 74. N 2. P. 145.

[6] Schmidt $W$. Optical Spectroscopy in Chemistry and life Sciences. Wiley-VCH, 2005. 384 p.; Шмидт В. Оптическая спектроскопия для химиков и биологов. М.: Техносфера, 2007. $368 \mathrm{c}$.

[7] Вязьмин С.Ю., Рябухин Д.С., Васильев А.В. Электронная спектроскопия органических соединений / Учебное пособие. СПб.: СПбГЛТА, 2011. 43 с.

[8] Радциг А.А., Смирнов Б.М. Справочник по атомной и молекулярной физике. М.: Атомиздат, 1980. 240 с.

[9] Большаков Г.Ф., Ватаго В.С., Агрест Ф.Б. Ультрафиолетовые спектры гетероорганических соединений / Справочное руководство. Л.: Химия, 1969. 504 с.

[10] Грудинкина Н.П. // Опт. и спектр. 1956. Т. 1. В. 5. С. 658.

[11] Словецкий В.И. // Успехи химии. 1971. Т. XL. № 4. С. 740; Slovetskii V.I. // Russ. Chem. Rev. 1971. V. XL. N 4. P. 393.

[12] Кукушкина И.И. Электронная спектроскопия поглощения сложных молекул / Метод. пособие. Кемерово: Кузбассвузиздат, 2000. $83 \mathrm{c}$.

[13] Шубина Д.М., Пацаева С.В., Южаков В.И., Горикова О.М., Федосеева Е.В. // Вода: химия и экология. 2009. № 11. C. 31.

[14] Banwel C.N. Fundamentals of Molecular Spectroscopy. McGraw-Hill, 1994. 308 p.; Бенуэлл К. Основы молекулярной спектроскопии. М.: Мир, 1985. 384 с.

[15] Невоструев В.А., Миклин М.Б. // Химия высоких энергий. 1987. T. 21. № 2. C. 154.

[16] Захаров Ю.А, Невоструев В.А. // Успехи химии. 1968. T. 37. № 1. C. 143; Zakharov Yu.A., Nevostruev V.A. // Russ. Chem. Rev. 1968. V. 37. N 1. P. 61.

[17] Ravindran P., Delin A., Johansson B., Eriksson O. // Phys. Rev. B. V. 59. N 3. P. 1776.

[18] Журавлев Ю.Н., Поплавной А.С. Электронное строение оксианионных кристаллов. Томск: Изд-во Томского гос. пед. ун-та, 2008. $194 \mathrm{c.}$

[19] Журавлев Ю.Н., Корабельников Д.В. // ФТТ. 2009. Т. 51. № 1. C. 65; Zhuravlev Yu.N., Korabel'nikov D.V. // Phys. Sol. St. 2009. T. 51. N 1. C. 69.

[20] Миклин М.Б. // Вестник Кемеровского государственного университета. 2014. Т. 3. № 3. С. 234.

[21] Zijun Yu., Bernstein E.R. // J. Chem. Phys. 2011. V. 135. N 15. doi 10.1063/1.3652893

[22] Алукер Н.Л., Сахарчук Ю.П., Иванова Е.В. // Бутлеровские сообщения. 2012. Т. 30. № 5. С. 117.

[23] Алукер Н.Л., Иванова Е.В., Зверев А.С. // Бутлеровские собщения. 2012. Т. 31. № 8. С. 53.

[24] Mullen P.A., Orloff M.K. // J. Phys. Chem. 1973. V. 77. N 7. P. 910. 